Article Type: Research Paper

\title{
Forecasting Fisheries Production in Indonesia
}

\author{
Bayu Rhamadani Wicaksono ${ }^{1 *}$, Tendi Sutandi ${ }^{2}$, and Sydney Tembo ${ }^{3}$
}

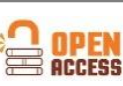

\section{AFFILIATION:}

${ }^{1}$ Graduate School of Economics, Ritsumeikan University, Japan.

2, 3 Graduate School of International Relations, International University of Japan (IUJ), Japan

\section{*CORRESPONDENCE:}

gr0441kr@ed.ritsumei.ac.jp

THIS ARTICLE IS AVALILABLE IN:

http://journal.umy.ac.id/index.php/esp

DOI: 10.18196/jesp.21.2.5039

\section{CITATION:}

Wicaksono, B. R., Sutandi, T., \& Tembo, S. (2020). Forecasting Fisheries Production in Indonesia. Jurnal Ekonomi \& Studi Pembangunan, 21(2), 170-184.

\section{ARTICLE HISTORY}

Received:

25 June 2020

Reviewed:

12 Sep 2020

Revised:

15 Sep 2020

Accepted:

08 Oct 2020
Abstract: The abundance of water resources avails Indonesia an excellent advantage in terms of the development of the capture and aquaculture fisheries. In recent years, Indonesian fish production has shown an increasing trend. The capture and aquaculture fisheries reached 6.6 million and 16.0 million tonnes respectively in 2016. The growing trend was translated into an average contribution of 2.4 percent towards the national GDP in 2013-2017. However, the absence of forecasting methods and data on fisheries production's potential growth contributes to ineffective policy interventions that require optimum production. Therefore, this study's main objective is to find the most accurate forecasting method for Indonesia's fisheries production. This research utilized the quarterly data of Indonesian fisheries production in 2000-2018 obtained from the Ministry of Marine Affairs and Fisheries. A comparative analysis of the Double Exponential and Seasonal ARIMA (SARIMA) method was undertaken to arrive at the most accurate forecasting method. The study findings broadly revealed that Indonesia's fish production was on an increasing trend, with aquaculture fisheries' contribution outweighing the capture fisheries in recent years. Furthermore, the SARIMA method was found to be the most accurate forecasting method compared to the Double Exponential method. The findings are useful for the government and related stakeholders for enhancing fish productivity in Indonesia. In addition, SARIMA methods could be used to forecast the fish production in upcoming years for better policy, strategy, and decision-making in developing the fisheries sector in Indonesia.

Keywords: Double Exponential; Fisheries Production; Seasonal Autoregressive Integrated Moving Average (SARIMA)

JEL Classification: C22; C53; E23; E27; Q22

\section{Introduction}

Indonesia is the largest country in Southeast Asia that extends from $6^{\circ}$ North Latitude to $11^{\circ}$ South Latitude and from $95^{\circ}$ to $141^{\circ}$ East Longitude. The territory is influenced by tropical climate due to its location along the equator. The territory is inhabited by a diversity of flora and fauna. Indonesia's land area covers 1.3 percent of the earth's surface and is a big home for 12 percent of mammals, 16 percent of reptiles and amphibians, 17 percent of birds, 10 percent of plants, and 25 percent of fish species (World Wildlife Fund (WWF) Indonesia, 2018). Under the United Nations Convention on the Law of the Sea (UNCLOS) 1982, the manageable ocean water area covered by $2 / 3$ of all Indonesian area, is approximately 5.9 million km2 (Organization for Economic Cooperation and Development (OECD), 2013). 


\author{
Wicaksono, Sutandi, \& Tembo \\ Forecasting Fisheries Production in Indonesia
}

This geographical location and abundance of water resources present a huge potential for fisheries resources from the natural water bodies. It gives Indonesia a preferential benefit to undertake capture fisheries production, unlike aquaculture production. According to Indonesian Law Number 31/2004 about fisheries, capture fisheries refer to activities to catching fish. Meanwhile, aquaculture fisheries involve raising fish in a controlled environment (Government of the Republic of Indonesia, 2004).

The capture fisheries in Indonesia are both marine and inland open water fisheries. However, to control the fish stock's overexploitation, the government has put in place fisheries regulatory measures, including the Maximum Sustainable Yield (MSY), as a global best practice. The MSY is the highest possible catch to sustain the fish stock by keeping maximum growth (Garcia, 1996). The Maximum Sustainable Yield (MSY) in capture fisheries is approximately 6.4 million tonnes per year, with the Total Allowable Catch (TAC) around 5.12 million tonnes per year or 80 percent of MSY (OECD, 2013). The potency is yet not fully exploited, which was only 5.4 million tons of catching in 2013 or 93 percent of the TAC although, in the following years, the production of capture fisheries reached 6.5 million tonnes in 2014, with a further increase of 6.6 million tonnes in 2016 (Ministry of Marine Affairs and Fisheries, 2019b). The figures imply that the fish production from capture fisheries is already in the overexploited condition. Suman, Irianto, Satria, and Amri (2016) argued that 86 percent of Indonesian fishing ground in overfishing and fully exploited conditions.

Furthermore, the national fish production can be sealed by expanding aquaculture production in addition to filling the capture fisheries overexploited. Tran, Rodriguez, Chan, Philips, Mohan, Henriksson, Koeshendrajana, Suri, \& Hall (2017) argued that aquaculture became the main driver of fish supply growth with 7.7 percent annual growth and 40 percent shares in 2014. Aquaculture fisheries production reached 14.4 million tonnes in 2014 and thereafter rose to 15.6 million tonnes and 16.0 million tonnes in 2015 and 2016, respectively (Ministry of Marine Affairs and Fisheries, 2019a).

According to Badan Pusat Statistik (BPS)/ BPS-Statistics Indonesia (2018), the contribution of the fisheries sector to the Gross Domestic Product (GDP) of Indonesia showed an increasing trend with an average of 2.4 percent between the 2013 and 2017 periods. In 2016, the fisheries sectors grew by 5.2 percent, recording a 2.56 percent contribution to the national GDP, with a total of IDR 214.5 trillion. Additionally, it grew by 5.95 percent in 2017 with the contribution towards national GDP at 2.57 percent, with a total of IDR 227.3 trillion. One of the influencers of those increasing trends is fisheries production.

The government and several stakeholders have made significant interventions in enhancing fisheries sector productivity. The fisheries sector's critical role is reinforced by the government regulations in Nawa Cita's priority agenda and the National MediumTerm Development Plan/ Rencana Pembangunan Jangka Menengah Nasional (RPJMN). It states that maritime and marine economies are conducted by increasing fisheries production in the upcoming years (Ministry of Marine Affairs and Fisheries, 2016). In view of the sector's immediate past performance, it is anticipated that its growth and contribution towards GDP will continue to rise. However, there is an absence of 
forecasted data on the potential growth of fisheries production. It is likely to contribute to ineffective intervention strategies as decision making is not based on informed data. This study aims to identify the best forecasting method for fisheries production in Indonesia.

The previous studies sought to forecast Indonesian fish production for various purposes with different methods (Fitri, Gamayanti, \& Darmawan 2017; Azhar \& Riksakomara 2017). Fitri et al. (2017) used Singular Spectrum Analysis (SSA) method to forecast fish production in West Java Province, Indonesia; thus, it could be identified whether the fish production could fulfill fish provision consumption. Azhar and Riksakomara (2017) forecasted the fish production to manage fish distribution in Banjarmasin Fishing Port, Indonesia, using the Artificial Neural Network (ANN) method to process the data mimicking the workings of the human nervous system.

Several studies compared the time series of forecasting methods to forecast the fisheries activities (Xie, Hong, \& Wohlin 1998; Akkurt, Demirel, \& Zaim 2010; llah 2016; Raman Sathianandan, Sharma, \& Mohanty, 2017; Karunarathna \& Karunarathna 2017). Xie et al. (1998) compared Double Exponential, GO model, and S-Shaped models to predict the number of software errors. The study found that the Double Exponential method provided a more accurate result than two other methods in forecasting the number of software errors. Akkurt et al. (2010) compared the method of exponential smoothing, winter forecasting, and Seasonal ARIMA (SARIMA) to forecast Turkey's national gas consumption. The findings suggested that the best forecasting method depended on the data set. Double Exponential is more powerful for the yearly data set than the others, while the SARIMA model is more powerful for the monthly data set. Ilah (2016) argued that determining fisheries export development required an appropriate forecasting method based on past data. In this case, ARIMA $(0,1,1)(1,0,2) 12$ is the best model to forecast fresh/frozen shrimp while ARIMA $(0,1,0)(1,0,0) 12$ is the best model for the export of cob/tuna forecast. Raman et al. (2017) found that the ARIMA model with logtransformed data performed better to forecast Odisha's fish landing in 2013-2015. Meanwhile, Karunarathna and Karunarathna (2017) found that ARIMA $(1,1,1)$ was the best method to forecast Sri Lanka's annual fish production.

Specifically, based on the background and problem identification, this study aims to compare univariate time series forecasting methods: Double Exponential and Seasonal Autoregressive Integrated Moving Average (SARIMA). This research used the quarterly data of Indonesian fisheries production during the 2000-2018 periods. The Double Exponential method represented the simple forecasting method, while SARIMA represented the complex forecasting method, including the seasonal factors in the quarterly data (Box \& Jenkins, 1976).

This research has three objectives: understanding the general description of fisheries production in Indonesia, selecting the most accurate time series method for forecasting fisheries production in Indonesia, and forecasting the predicted results of fisheries production in Indonesia for upcoming years. The hypothesis testing is that the SARIMA method is more accurate than the Double Exponential method. 
Hopefully, the best method's predicted results are essential for stakeholders and policymakers in Indonesia. The government can use the predicted results of fisheries production to make future planning and regulations suitable for the development of fisheries production. Moreover, the government can also use the predicted results as an alternative consideration to make other targets in the future, such as the number of fisheries consumption and export.

\section{Research Method}

This research used quarterly data on fisheries production in Indonesia from 2000 to 2018. The data source was the secondary data obtained from the Ministry of Marine Affairs and Fisheries (MMAF). Running data for this study used software of Minitab 14, E-Views 10, and Microsoft Excel 2013.

Based on Mulyana (2004), Double Exponential is a popular technique for short-term forecasting for data. This method, using different smoothing constants, smoothed the levels and slopes directly. These smoothing constants provided an estimation of levels and slopes adjusted all-time when the new observations were available.

The three equations used in the Double Exponential method are as follows.

Exponential smoothing rows

$$
A_{t}=\alpha Y_{t}+(1-\alpha)\left(A_{t-1}+T_{t-1}\right)
$$

Trend estimation

$$
T_{t}=\beta\left(A_{t}-A_{t-1}\right)+(1-\beta) T_{t-1}
$$

Forecasting the next $p$ period

$$
\hat{Y}_{t+p}=A_{t}+p T_{t}
$$

with:

$A_{t} \quad=$ new smoothing values

$\alpha \quad=$ smoothing constants of data $(0 \leq \alpha \leq 1)$

$Y_{t} \quad=$ new observations of the actual value in the period $t$ series

$\beta=$ smoothing constants of trend estimation $(0 \leq \beta \leq 1)$

$T_{t} \quad=$ trend estimation

$p \quad=$ periods of the next forecast

$\hat{Y}_{t+p}=$ forecasted value of $p$ periods

Based on Box and Jenkins (1976), the ARIMA method do not need a specific assumption about historical data from the periodic series, but it used iterative methods to obtain the best model. Furthermore, the selected model would be re-checked with historical data, 
whether it already described the suitable data or not. The best model would be obtained when the residual between the forecasting model and historical data was small, random, and independent. If the model chosen was not able to explain well, the model needed to be repeated. Generally, the equation of ARIMA is as follows.

$$
\left(1-\sum_{h=1}^{p} \emptyset_{h} B^{h}\right)(1-B)^{d} Y_{t}=\left(1-\sum_{i=1}^{q} \theta_{i} B^{i}\right) \varepsilon_{t}
$$

with:

$Y_{t} \quad=$ dependent variables at $t$ time

$\emptyset_{h} \quad=$ lag regression coefficient of $Y$

$\theta_{i} \quad=$ lag regression coefficient of residual

$(1-B)^{d}=$ differencing the $d$ order

$\varepsilon_{t} \quad=$ error term/residual

$p \quad=$ number of orders in the Auto-Regressive model

$d \quad=$ number of differencing process

$q \quad=$ number of orders in the Moving Average model

The seasonal data were defined as a time series with a repetitive auto pattern from one year to another. Both observations within a year and inter-year observations were intercorrelated. The autocorrelation plot could detect the existence of a seasonal pattern on the data. Generally, ARIMA for seasonal data or Seasonal Autoregressive Integrated Moving Average (SARIMA) model is as follows.

$$
\Phi_{P}\left(B^{S}\right) \phi_{p}(B) \nabla_{s}^{D} \nabla^{d} z_{t}=\theta_{q}(B) \Theta_{Q}\left(B^{S}\right) a_{t}
$$

with:

$\Phi_{P}\left(B^{S}\right)=$ the seasonal Auto-Regressive model of order $\mathrm{P}$

$\phi_{p}(B)=$ the regular Auto-Regressive model of order $\mathrm{p}$

$\nabla_{S}^{D} \quad=$ the seasonal differences

$\nabla^{d} \quad=$ the regular differences

$\Theta_{Q}\left(B^{S}\right)=$ the seasonal Moving Average model of order $\mathrm{Q}$

$\theta_{q}(B)=$ the regular Moving Average model of order $\mathrm{q}$

$a_{t} \quad=$ a white noise process

Every forecasting method selected must be evaluated in terms of reliability and capability when applied to encountered problems, cost-effectiveness, and accuracy. The forecasting accuracy was frequently considered based on a comparison between the original series and the forecasting series. The difference between the actual values and the forecast values is usually expressed as residuals. Comparing the accuracy among several forecasting models can use five measurements. 


\section{Mean Square Error (MSE)}

The first measure to evaluate forecasting methods is MSE. This approach shows extensive forecasting residual as its residual value is squared. The formulation of MSE is:

$$
M S E=\frac{1}{n} \sum_{t=1}^{n}\left(Y_{t}-\hat{Y}_{t}\right)^{2}
$$

\section{Root Mean Square Error (RMSE)}

RMSE is the generated value from the MSE's root. RMSE is very useful to measure residual forecasts in the same unit as the original series. The formulation of RMSE is:

$$
R M S E=\sqrt{M S E}=\sqrt{\frac{1}{n} \sum_{t=1}^{n}\left(Y_{t}-\hat{Y}_{t}\right)^{2}}
$$

\section{Mean Absolute Deviation (MAD)}

MAD measures the accuracy of forecasting through the absolute value of each residual. Like RMSE, MAD is very useful to measure residual forecasts in the same unit as the original series. The following equation shows how to measure MAD:

$$
M A D=\frac{1}{n} \sum_{t=1}^{n}\left|Y_{t}-\hat{Y}_{t}\right|
$$

\section{Mean Absolute Percentage Error (MAPE)}

MAPE can also be used to compare the accuracy of various similar or different methods in some different series. Here is how to calculate MAPE:

$$
M A P E=\left(\frac{1}{n} \sum_{t=1}^{n} \frac{\left|Y_{t}-\hat{Y}_{t}\right|}{Y_{t}}\right) X 100 \%
$$

\section{Result and Discussion}

Figure 1 shows that the capture fisheries production from 2000 to 2009 has been more extensive than the aquaculture fisheries production. However, there was a contrary condition after that period. The production of aquaculture fisheries between 2010 and 2018 increased significantly. It took twice from 11.7 million to 23.8 million tonnes. 


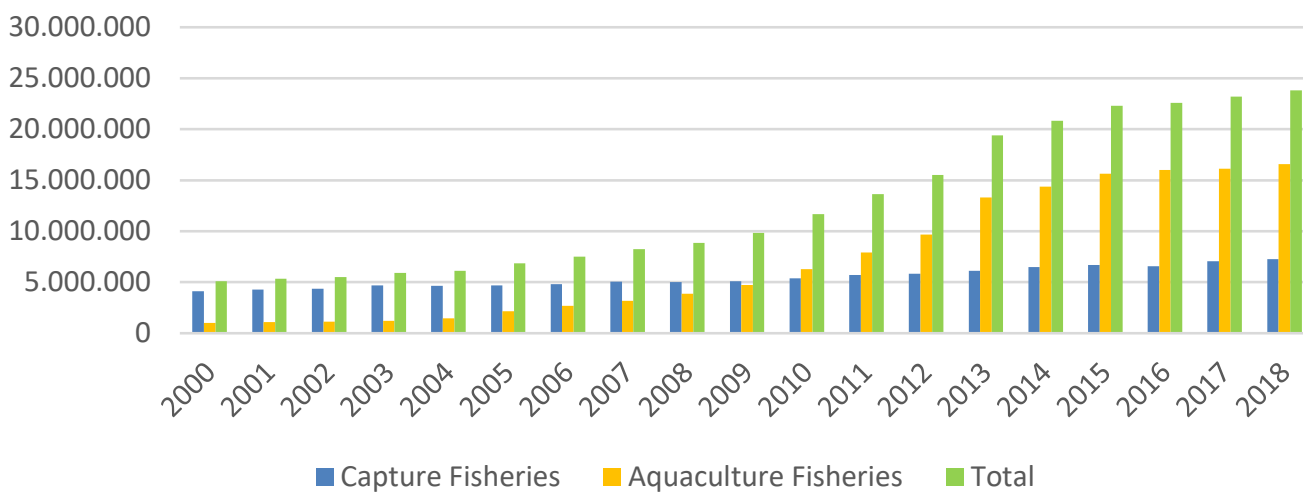

Figure 1 The Number of Fisheries Production in Indonesia, 2000-2018 (Tonnes) Source: Ministry of Marine Affairs and Fisheries, 2019

The capture fisheries were an effort to catch fish and other aquatic organisms in nature (sea, river, lake, and others). Humans do not intentionally control aquatic organisms' lives in nature and its factors (biotic and abiotic). In contrast to the capture fisheries, the aquaculture fisheries were operated on land using a water pool or a tank and a protected water body. Thus, the fishes that were kept did not escape to nature. The aquaculture fisheries mimicked a system found in nature to breed and raise the fish.

The fisheries sector was a part of the natural resource economy, so its existence is very strategic in providing a significant contribution to national development. In fact, the Food and Agriculture Organization (FAO) has predicted that fisheries will become one of the resources that will be immensely reliable in the future, especially in fulfilling the food needs and empowering the economy of the global community (Cocon, 2017).

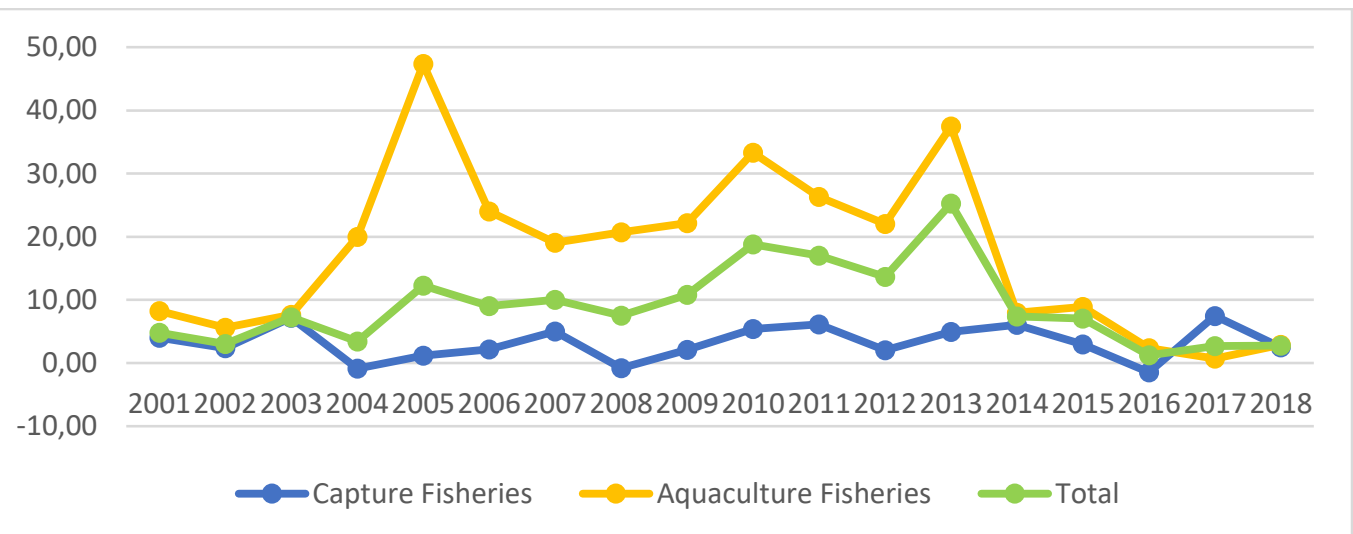

Figure 2 The Growth of Fisheries Production in Indonesia, 2001-2018 (Percent) Source: Ministry of Marine Affairs and Fisheries, 2019

Figure 2 shows three views that can describe the growth of fisheries production in Indonesia. First, the highest growth in 2013, approximately 25.23 percent, was recorded for total fisheries production. Second, the capture fisheries production reached the highest growth of about 7.47 percent in 2017. Last, aquaculture fisheries production 
experienced the highest growth in 2005, which was 47.33 percent. All in all, the recent growth was not as massive as in previous years; even the growth has declined from 2014 to 2016 . However, based on Figure 1, fisheries production has an increasing trend.

Specifically, the performance of aquaculture fisheries production also showed a positive trend, in which the production tended to increase on average per year to 19.08 percent in the 2011-2015 period. This result recorded Indonesia as the second producer of world aquaculture. In 2014, Indonesia contributed at least 14.22 percent of the total world aquaculture production and ranked second after China, which still dominated 58.16 percent (Cocon, 2017).

\section{Double Exponential}

Figure 3 shows a plot of the original data and linear regression over time. The Indonesian fisheries production data are the quarterly data from 2000 to 2018.

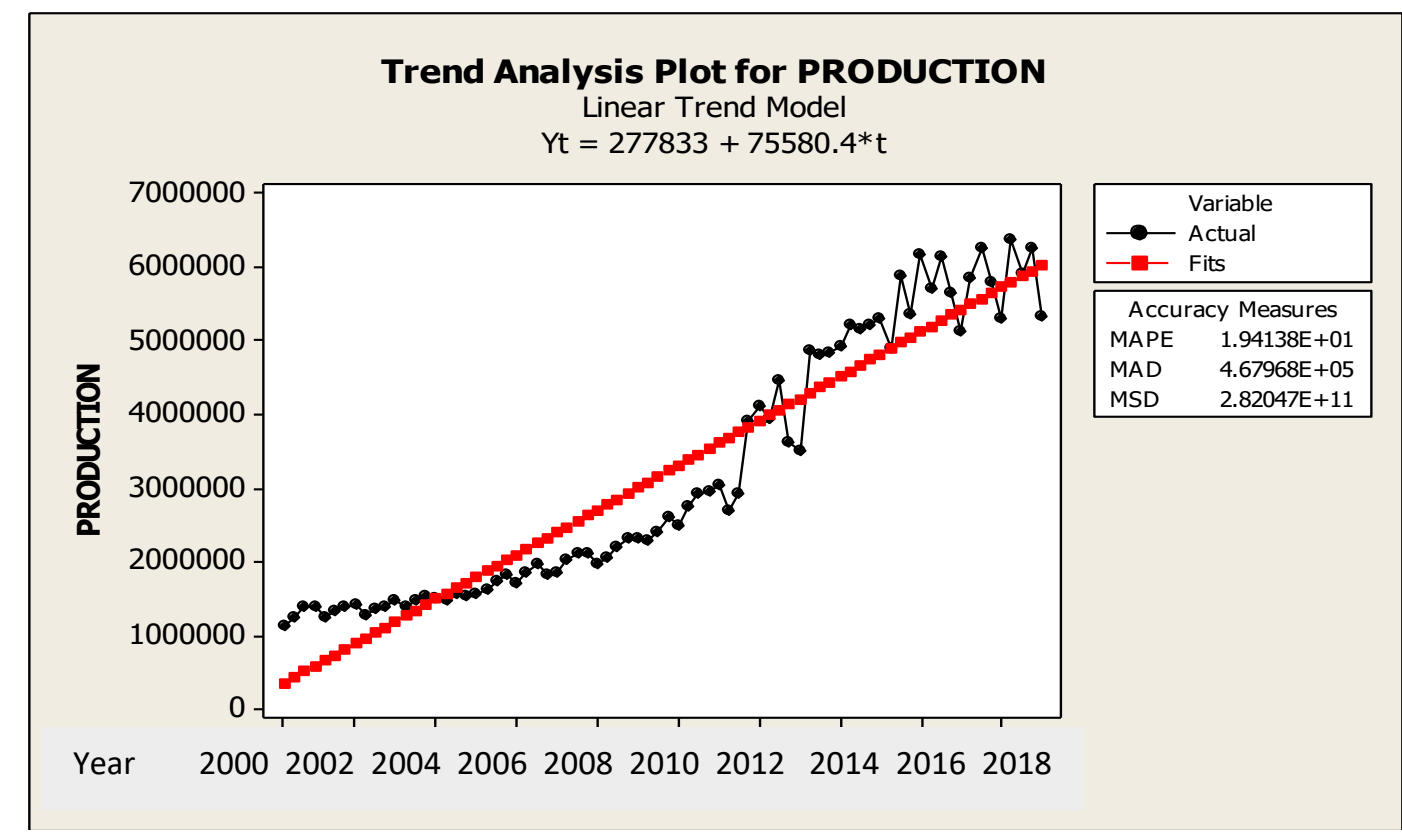

Figure 3 Trend Analysis Plot for Fisheries Production

Source: Authors, 2020

Furthermore, Figure 3 depicts that Indonesian fisheries production data's movement has a linear trend pattern where the trend's propensity has increased year to year. As Indonesian fisheries production data has a trend, the chosen Exponential Smoothing method is the Double Exponential. 


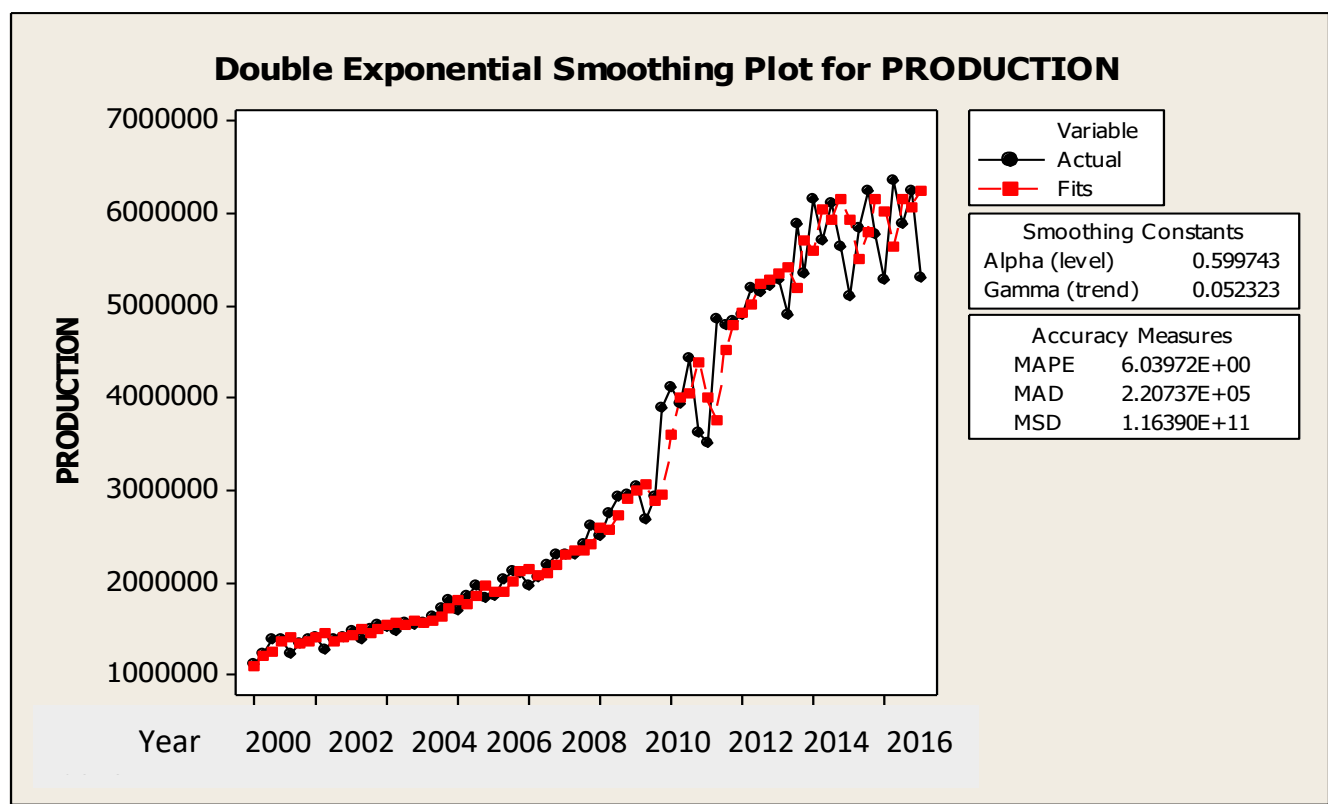

Figure 4 Double Exponential Smoothing Plot for Fisheries Production Source: Authors, 2020

Based on the Double Exponential method in Figure 4, a model of Indonesian fisheries production can be obtained with $\alpha=0.599743$ and $\beta=0.052323$. Testing for the residual model for Indonesian fisheries production can be seen from the residual Autocorrelation Function (ACF) plot.

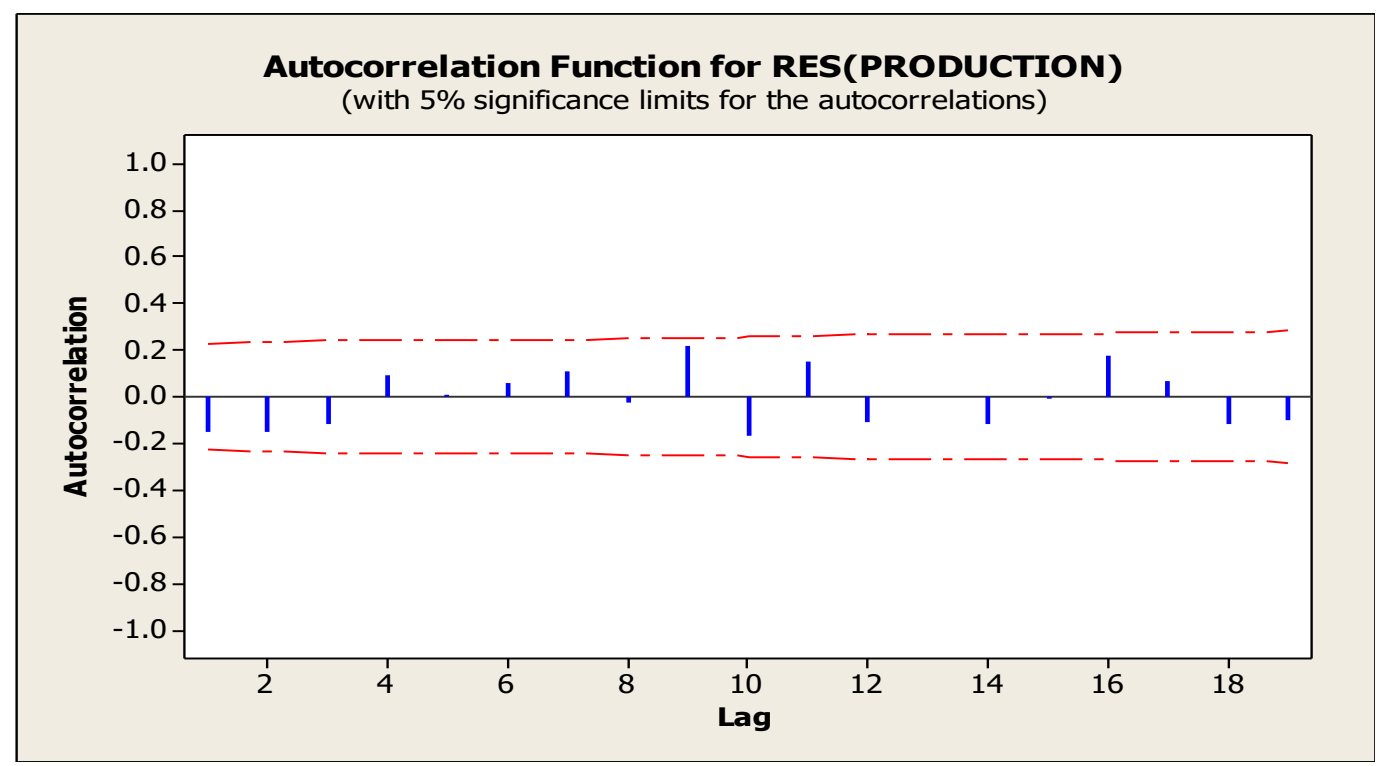

Figure 5 Autocorrelation Function for Residual of Fisheries Production Source: Authors, 2020

Moreover, based on the residual ACF plot in Figure 5, all intervals' autocorrelation coefficient is insignificant. This result showed that the series was random; thus, the 
model was appropriate and adequately explained the data. Meanwhile, based on Figure 4, the Double Exponential equation is described as follows.

$$
\begin{gathered}
\widehat{Y}_{t+p}=0.599743 Y_{t}+0.400257\left(A_{t-1}+T_{t-1}\right)+p\left(0.052323\left(A_{t}-A_{t-1}\right)\right. \\
\left.+0.947677 T_{t-1}\right)
\end{gathered}
$$

\section{Seasonal ARIMA (SARIMA)}

Based on Figure 3, it can be seen that the data has a trend; thus, it is concluded that the data are not stationary at the level. It is further confirmed by the formal PhillipsPerron unit root test in Table 1.

Table 1 Phillips-Perron Unit Root Test on Production

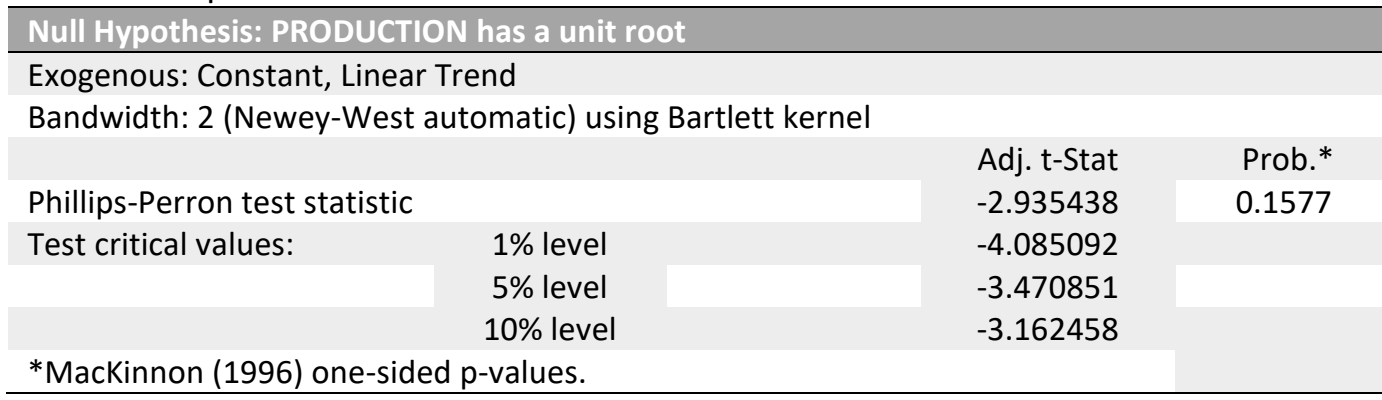

Source: Authors, 2020

Based on Table 1, the result shows that the $p$-value of fisheries production ( 0.1577$)$ was larger than the value of $\alpha(0.05)$. Therefore, it is necessary to do a differencing process so that the data will be stationary.

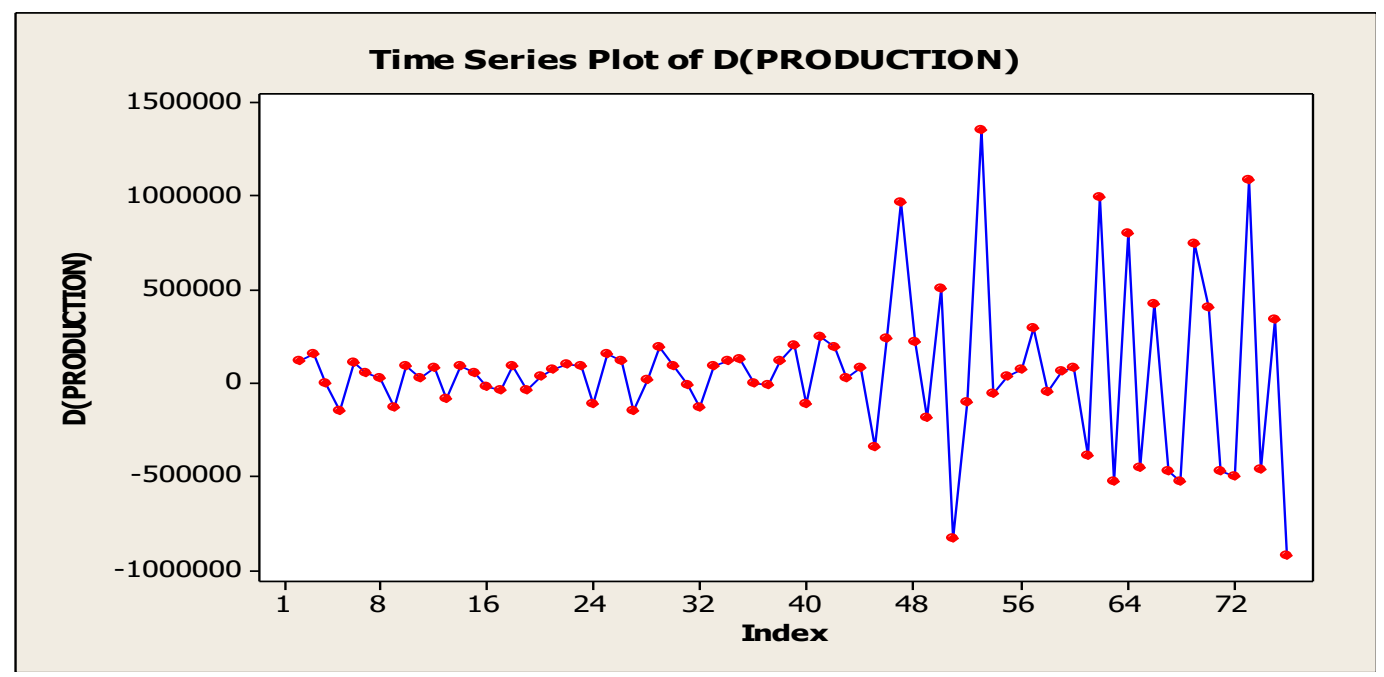

Figure 6 Plot of Fisheries Production Data in First Differencing Source: Authors, 2020 
In Figure 6, it can be seen that the Indonesian fisheries production was stationary at first differencing. It was confirmed by examining the stationary of data on the first differencing through the Phillips-Perron unit root formal test.

Table 2 Phillips-Perron Unit Root Test on d(Production)

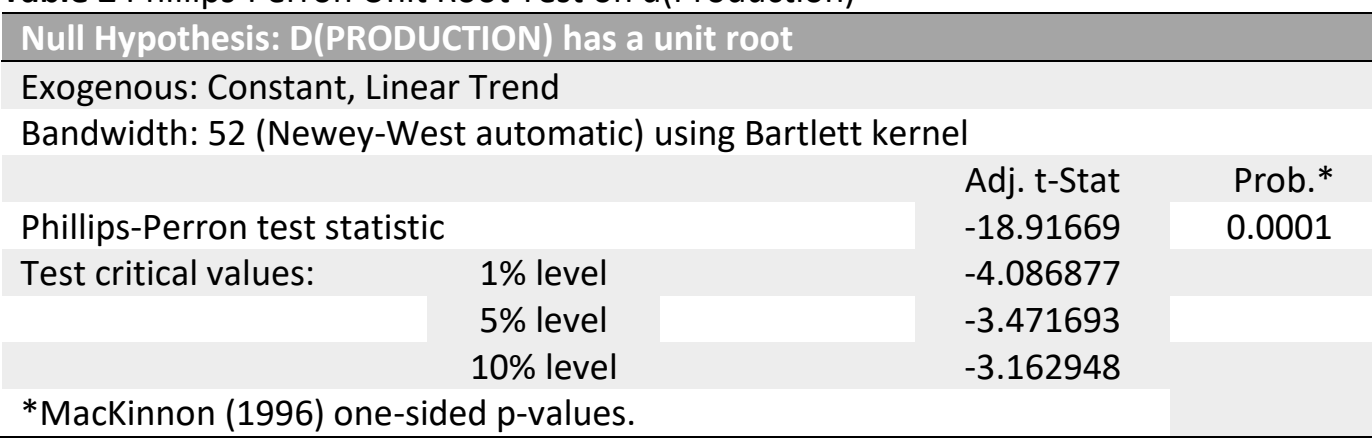

Source: Authors, 2020

Furthermore, in Table 2, the test result showed that the $p$-value of fisheries production $(0,0001)$ was smaller than the value of $\alpha(0.05)$, so the data were stationary. Therefore, it can be concluded that Indonesian fisheries production data were eligible for the test of Seasonal ARIMA (SARIMA). The next step was to identify the SARIMA model that could be completed by comparing the Autocorrelation Function (ACF) and Partial Autocorrelation Function (PACF) patterns from the stationary data. However, there was a possibility of obscurity in determining the best SARIMA model so that identification could also be conducted by trial and error method (Box \& Jenkins, 1976).

Table 3 The Possibility of SARIMA Model

\begin{tabular}{ccc}
\hline No. & SARIMA Model & Mean Square \\
\hline$(1)$ & $(2)$ & $(3)$ \\
1 & ARIMA $(0,1,1)(0,1,1)_{4}$ & $116,318,730,247$ \\
2 & ARIMA $(1,1,0)(0,1,1)_{4}$ & $126,911,538,380$ \\
3 & ARIMA $(1,1,2)(0,1,1)_{4}$ & $94,333,239,916$ \\
\hline
\end{tabular}

Source: Authors, 2020

Based on the result in Table 3, three SARIMA models were obtained that has significant parameters for Indonesian fisheries production data. ARIMA $(1,1,2)$ $(0,1,1)_{4}$ is the best model as it had a smaller Mean Square (MS) value than the other models. The selected SARIMA model estimator must be a model that is able to explain the data well. This examination can be carried out by looking at the correlogram through the ACF for residual.

Based on Figure 7, there was no significant residual in Indonesian fisheries production data. A comprehensive examination of the model's adequacy can be used in the ChiSquare test $\left(\chi^{2}\right)$ based on Ljung-Box $Q$ statistics. 


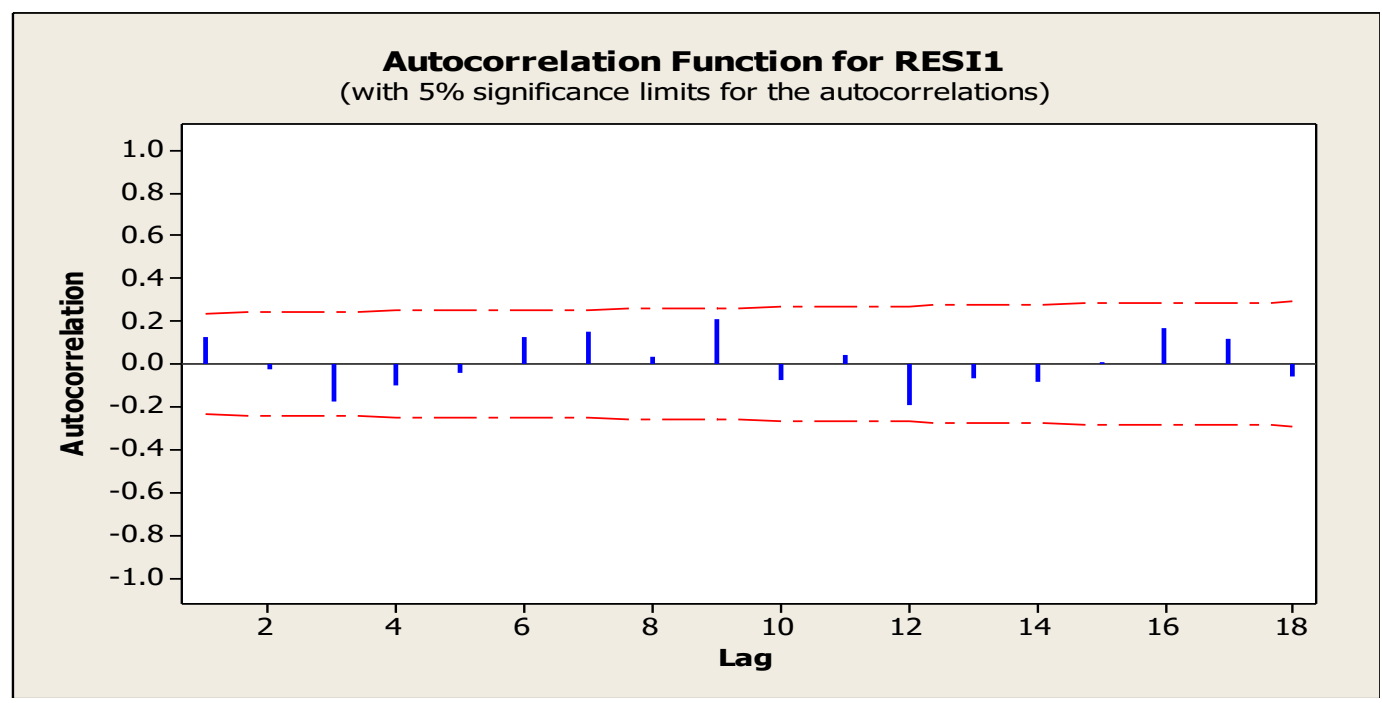

Figure 7 Autocorrelation Function for Residual ARIMA $(1,1,2)(0,1,1)_{4}$ Source: Authors, 2020

In Table 4, the result indicates that the Indonesian fisheries production model was adequate as there was the insignificance of the $p$-value in all selected lag samples. The results of the two types of checks showed that the residuals are random.

Table 4 Modified Box-Pierce (Ljung-Box) Chi-Square Statistics

\begin{tabular}{lcccc}
\hline Lag & 12 & 24 & 36 & 48 \\
\hline Chi-Square & 15.5 & 25.5 & 28.5 & 30.4 \\
df & 8 & 20 & 32 & 44 \\
p-value & 0.050 & 0.184 & 0.643 & 0.941 \\
\hline
\end{tabular}

Source: Authors, 2020

To get a suitable model in forecasting fisheries production in Indonesia, it is necessary to test the accuracy of the model obtained between the Double Exponential and SARIMA method. In Table 5, comparing the value of four criteria for the model accuracy can be concluded that the SARIMA method was more accurate for forecasting fisheries production in Indonesia.

Table 5 The Comparison of Accuracy between Double Exponential and SARIMA

\begin{tabular}{ccc}
\hline Criteria & Double Exponential & ARIMA $(1,1,2)(0,1,1)_{4}$ \\
\hline$(1)$ & $\mathbf{( 2 )}$ & $\mathbf{( 3 )}$ \\
MSE & $1.16390 \mathrm{E}+11$ & $0.94333 \mathrm{E}+11$ \\
RMSE & $341,159.79$ & $307,137.17$ \\
MAD & $2.20737 \mathrm{E}+05$ & $4.17817 \mathrm{E}+02$ \\
MAPE & 6.03972 & 0.15450 \\
\hline
\end{tabular}

Source: Authors, 2020

Upon obtaining the best model, forecasting can be done using the equation of the chosen method. The model of ARIMA $(1,1,2)(0,1,1)_{4}$ presented the predicted value of 
Indonesian fisheries production in 2019 compared to the preliminary number from the Ministry of Marine Affairs and Fisheries.

Table 6 The Predicted Value and Preliminary Number of Fisheries Production in Indonesia, 2019 (Tonnes)

\begin{tabular}{cccc}
\hline Year & Quarter & $\begin{array}{c}\text { Predicted Value } \\
\text { (Authors) }\end{array}$ & $\begin{array}{c}\text { Preliminary Number } \\
\text { (MMAF) }\end{array}$ \\
\hline$(1)$ & $(2)$ & $(3)$ & $(4)$ \\
2019 & 1 & $5,945,490$ & $6,032,798$ \\
& 2 & $6,059,133$ & $6,323,112$ \\
& 3 & $5,926,227$ & $6,572,446$ \\
& 4 & $5,752,931$ & $5,798,512$ \\
\hline
\end{tabular}

Source: Authors, 2020 \& Ministry of Marine Affairs and Fisheries, 2019

By referring to the result in Table 6, each quarter's predicted value was relatively close to the preliminary number from the Ministry of Marine Affairs and Fisheries. The government can continue to increase Indonesian fisheries production, which is expected to be able to fulfill the needs of domestic consumption and export in the future. It is not difficult as Indonesia has a comparative advantage compared to other countries, such as the abundance of labor and natural resources as raw materials. However, the comparative advantage cannot always be used as the frontline. In the current free trade era, Indonesia must also create other advantages that can be developed, such as the competitive advantage (Tambunan, 2004).

\section{Conclusion}

The key findings of this study are that fish production was on an increasing trend. Indonesian fisheries production presented an increasing trend with a linear pattern during the 2000-2018 periods. The study revealed the shifting dominance from capture to aquaculture fisheries. The capture fisheries production was more significant than aquaculture fisheries production in the period 2000-2009. However, the fisheries production from aquaculture between 2010 and 2018 increased significantly as its recorded growth doubled. It is such adequate evidence and justification for prioritizing substantial actions, such as investments, into aquaculture to increase Indonesia's fisheries production.

Furthermore, the research revealed that the SARIMA model was the selected forecasting method. Based on the comparison of accuracy measurements, the SARIMA, as a forecasting method for Indonesian fisheries production, was more accurate than the Double Exponential. In addition, the predicted value for each quarter in 2019 using ARIMA $(1,1,2)(0,1,1) 4$ was relatively close to the preliminary fish production obtained from the Ministry of Marine Affairs and Fisheries. It was called for enhancing capacity building in the use of SARIMA as a fisheries forecasting method in Indonesia.

This research only used one variable (fisheries production) and univariate time series methods for forecasting that variable. In reality, there were several variables with time 
series data that also had linkage with the fisheries sector, such as fisheries consumption and export. Moreover, there was also multivariate time series methods that can be used to analyze several variables, such as Vector Autoregression (VAR) and Error Correction Model (ECM). However, the study laid on a foundation for further research focusing on the omitted variables.

\section{References}

Akkurt, M., Demirel, O. F., \& Zaim, S. (2010). Forecasting Turkey's Natural Gas Consumption by Using Time Series Methods. European Journal of Economic and Political Studies, 3(2), 1-21. Retrieved from https://arastirmax.com/en/system/files/dergiler/25821/makaleler/3/2/arastirmaxforecasting-turkeys-natural-gas-consumption-using-time-series-methods.pdf

Azhar, M., \& Riksakomara, E. (2017). Peramalan Jumlah Produksi Ikan dengan Menggunakan Backpropagation Neural Network (Studi Kasus: UPTD Pelabuhan Perikanan Banjarmasin). Jurnal Teknik ITS, 6(1), 142-148. http://dx.doi.org/10.12962/i23373539.v6i1.22129

Box, G., \& Jenkins, G. (1976). Time Series Analysis: Forecasting and Control. California: HoldenDay, Inc.

BPS-Statistics Indonesia. (2018). Quarterly Indonesian Gross Domestic Product, 2014-2018. (Subdirectorate of National Product Accounts Consolidation, Ed.). Jakarta: BPS-Statistics Indonesia.

Cocon. (2017, July). The Strategic Value of Aquaculture Fisheries in Supporting Food Security. Kompas.com. Retrieved from https://ekonomi.kompas.com/read/2017/07/24/161733226/nilai-strategisperikanan-budidaya-dalam-menopang-ketahanan-pangan

Fitri, F., Gamayanti, N. F., \& Darmawan, G. (2017). Metode SSA pada Data Produksi Perikanan Tangkap di Provinsi Jawa Barat. Jurnal Ilmiah Matematika dan Pendidikan Matematika (JMP), 9(2), 95-110. https://doi.org/10.20884/1.jmp.2017.9.2.2870

Garcia, S. (1996). Indicators for Sustainable Development of Fisheries. In the $2^{\text {nd }} W$ orld Fisheries Congress. Rome: The United Nations. Retrieved from http://www.fao.org/3/w4745e/w4745e0f.htm

Government of the Republic of Indonesia. Fishery (2004). Indonesia. Retrieved from https://www.ilo.org/dyn/natlex/docs/ELECTRONIC/89345/102625/F765882697 $\angle$ IDN89345 Eng.pdf

Ilah, M. (2016). Peramalan Jumlah Ekspor Indonesia pada Kelompok Komoditi Ekspor Udang Segar/Beku Dan Tongkol/Tuna dengan Metode Arima Box-Jenkins. Thesis. Institut Teknologi Sepuluh Nopember. Retrieved from http://repository.its.ac.id/584/2/1313030017-Non_Degree.pdf

Karunarathna, B., \& Karunarathna, K. A. N. K. (2017). Forecasting Fish Production in Sri Lanka by Using ARIMA Model. Scholafrs Journal of Agriculture and Veterinary Sciences, 4(9), 344-349. https://doi.org/10.21276/sjavs.2017.4.9.4

Ministry of Marine Affairs and Fisheries. (2016). Ministerial Decree Roadmap for Bureaucratic Reform of the Ministry of Maritime Affairs and Fisheries 2015-2019, Pub. L. No. 4/KEPMEN-KP/2016. Indonesia: Ministry of Marine Affairs and Fisheries. Retrieved from http://jdih.kkp.go.id/peraturan/4-kepmen-kp-2016.pdf 
Ministry of Marine Affairs and Fisheries. (2019a). Aquaculture Fisheries Statistics of Indonesia. (Directorate General of Aquacculture Fisheries, Ed.). Jakarta: Ministry of Marine Affairs and Fisheries.

Ministry of Marine Affairs and Fisheries. (2019b). Capture Fisheries Statistics of Indonesia. (Directorate General of Capture Fisheries, Ed.). Jakarta: Ministry of Marine Affairs and Fisheries.

Mulyana. (2004). Analysis of Time Series Data. Bandung: Padjadjaran University.

Organization for Economic Cooperation and Development (OECD). (2013). OECD Review of Fisheries: Policies and Summary Statistics 2013. Paris: OECD Publishing. http://dx.doi.org/10.1787/rev fish-2013-en

Raman, R. K., Sathianandan, R. T. V, Sharma, A. P., \& Mohanty, B. P. (2017). Modelling and Forecasting Marine Fish Production in Odisha Using Seasonal ARIMA Model. National Academy Science Letters, 40, 393-397. https://doi.org/10.1007/s40009-017$\underline{0581-2}$

Suman, A., Irianto, H. E., Satria, F., \& Amri, K. (2016). Potensi dan Tingkat Pemanfaatan Sumber Daya Ikan di Wilayah Pengelolaan Perikanan Negara Republik Indonesia (WPP NRI) Tahun 2015 serta Opsi Pengelolaannya. Jurnal Kebijakan Perikanan Indonesia, 8(2), 97-110. https://doi.org/10.15578/ikpi.8.2.2016.97-100

Tambunan, T. (2004). Globalisasi dan Perdagangan Internasional (Globalization and International Trade). Bogor: Penerbit Ghalia Indonesia.

Tran, N., Rodriguez, U., Chan, C. Y., Philips, M. J., Mohan, V., Henriksson, P. J. G., Koeshendrajana, S., Suri, S., \& Hall, S. (2017). Indonesian Aquaculture Futures : An Analysis of Fish Supply and Demand in Indonesia to 2030 and Role of Aquaculture using the AsiaFish Model. Marine Policy, 79, 25-32. https://doi.org/10.1016/j.marpol.2017.02.002

World Wildlife Fund (WWF) Indonesia. (2018). Species. Retrieved May 25, 2020, from https://www.wwf.or.id/program/spesies/

Xie, M., Hong, G. Y., \& Wohlin, C. (1998). A Study of the Exponential Smoothing Technique in Software Reliability Growth Prediction. Quality and Reliability Engineering International, 13(6), 347-353. https://doi.org/10.1002/(SICI)10991638(199711/12)13:6\%3C347::AID-QRE116\%3E3.0.CO;2-O 